\title{
The EMITRANSYS model and the possibilities of its application for the analysis of the development of sustainable transport systems
}

\begin{abstract}
The transport system has a direct impact on the economic and socio-economic situation of each country. Planning its development is an important element of policy. Bearing in mind the importance and complexity of this issue, it should be considered using both quantitative methods and mathematical models, as well as advanced simulation tools for modelling transport. The article presents a proposal for an approach to simulation tests of the different transport system in the aspect of the emission of harmful exhaust gas compounds from road transport. The tool for analysing and assessing the functioning of e xisting or designed systems is a model in which the properties of the real system, which are important from the point of view of the research objective, should be mapped. The Model of Proecological Transport System (MEST) was presented formally as an ordered four. Also elements of optimization taks shaping of proecological transport system in form of datas, decision variables, conditions and goal function were presented. An example of tests on simulation model was shown.
\end{abstract}

Key words: development of transport system, simulation tools, EMITRANSYS, mathematical model

\section{Introduction}

The transport system has a direct impact on the economic and socio-economic situation of each country [1]. Planning its development is an important element of policy [5]. Bearing in mind the importance and complexity of this issue, it should be considered using both quantitative methods and mathematical models, as well as advanced simulation tools for modelling transport. In these approaches, parameterization of models is an important element, which allows to achieve research goals with enough accuracy [6].

Typically, when analysing the operation of the different transport system, the transport subsystems of particular modes of transport are distinguished. Then, the research of these transport subsystems, the relationships between them, the impact of the environment on them and their surroundings are conducted. Interaction study of transport subsystems is an important element of modelling the transport system as a whole. These dependencies directly shape the modal split of transport tasks directed to the transport system from the environment [4]. At the same time, changes in the transport system lead to changes in the communication behaviour of residents, including changes in the demand for transport.

Summing up, modelling the development of the different transport systems, e.g. national, urban, regional, passengers and others, requires taking into account, among others:

- the needs of buyers of transport services along with their sensitivity to changes in the transport system,

- the existing and projected technical potential of transport service providers, including knowledge of restrictions on changes,

- the existing and forecasted condition of transport infrastructure, as well as investment opportunities in this respect,

- current and future solutions in the field of traffic organization in specific areas, regions,

- transport policy of a given country or region, including ecological conditions of the development of the transport system,
- the existing and projected negative impact of transport on the natural environment and the possibilities of its reduction.

Both socio-economic development and mutual cooperation of countries implies the development of transport needs, the implementation of which is carried out by various branches of transport. The division of transport tasks between particular branches of transport, especially in the conditions of a market economy, is primarily determined by the result of the economic account conducted by transport users. Until recently, the issues of transport ecology for many participants of the transport process were not significant, although many documents were issued in this area. Nowadays, the need to limit the negative impact of transport on the natural environment is a determinant of economic development.

The article presents a proposal for an approach to simulation tests of the national transport system in the aspect of the emission of harmful exhaust gas compounds from road transport.

\section{The development of transport and the emission of harmful exhaust gases}

Road transport is considered as the most harmful among transport branches. In 2016, road transport was responsible for almost $98 \%$ of greenhouse gas emissions emitted by transport $[2,24]$.

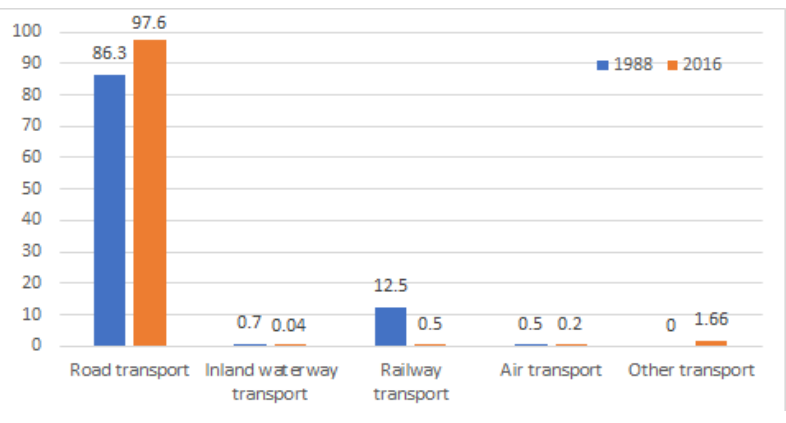

Fig. 1. $\mathrm{CO}_{2}$ emissions from fossil fuels by sectors in Poland [18] 
The negative impact of transport on the natural environment is expressed by [17]:

- greenhouse gas emissions contributing to climate change,

- local emission of air pollutants negatively affecting human health and the local natural environment,

- occupying valuable natural areas and cutting their continuity (fragmentation) with newly built sequences of technical infrastructure, contributing to the loss of biodiversity,

- noise emission threatening human health.

Air pollution emitted by vehicles depends on many factors. Among them can be distinguished: fuel composition, type and basic characteristics of vehicles, distribution of transport infrastructure, speed, places of congestion, etc. Among the air pollution measures can be distinguished: emission volume and concentration of individual primary pollutants (nitrogen oxides $\left(\mathrm{NO}_{\mathrm{x}}\right)$, carbon monoxide $(\mathrm{CO})$, sulphur dioxide $\left(\mathrm{SO}_{2}\right)$ and particulates $-\mathrm{PM}_{10}$ and $\mathrm{PM}_{2.5}$, as well as dust and soot). These pollutions can have a negative impact on materials and buildings, agricultural crops and forests, and can be harmful to human health and life. Figure 2 presents changes in $\mathrm{NO}_{\mathrm{x}}, \mathrm{CO}$ and particulate matter emissions of $\mathrm{PM}_{2.5}$ from road transport in Poland in recent years.

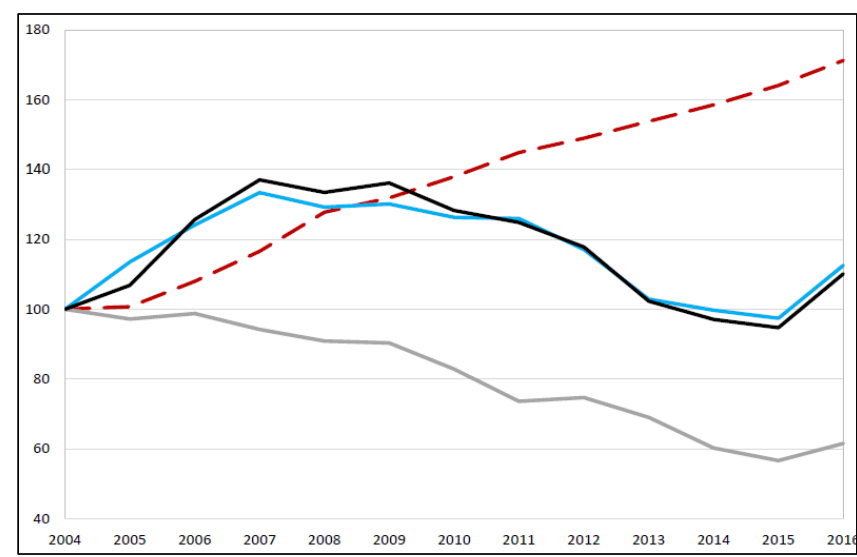

Fig. 2. Changes in emissions of $\mathrm{NO}_{x}, \mathrm{CO}$ and particulate matter $\mathrm{PM}_{2,5}$ from road transport in Poland in the years 2004-2016 in relation to the change in the number of cars and tractors, assuming that the volume of emissions in $2004=100 \%$ (Legend: red line - percentage change in the number of cars and tractors, blue line - percentage change in $\mathrm{NO}_{\mathrm{x}}$ emissions from road transport, grey line - percentage change in $\mathrm{CO}$ emissions from road transport, navy blue line - percentage change in $\mathrm{PM}_{2.5}$ emissions from road transport) [https://www.nik.gov.pl/plik/id,19075,vp,21678.pdf]

The emission of environmentally harmful substances from motor vehicles results not only from the composition and properties of fuels [21], as is the case for sulphur compounds, ring hydrocarbons and heavy metals. In addition due to the threat of the environment from the effects of global warming - the carbon dioxide emission, which is the most important due to the scale of greenhouse gas emissions from the combustion of fuels for internal combustion engines, is considered. An additional factor related to the impact of motorization on the environment are dusts consisting of, among others, from particulates $\left(\mathrm{PM}_{10}, \mathrm{PM}_{2.5}\right)$ (in 2011, the liner emission in Poland (connected with road transport) was responsible for 63 percent of $\mathrm{PM}_{10}$ concentration). At the same time, the amount of dust emissions resulting from fuel combustion in car engines is estimated at 7\%. A dozen of percent are particles from tires and brake pads. The remaining $80 \%$ results from the so-called secondary dusting, that is, from induction of dust lying on the ground in the air by passing cars. Summing up low emissions and cars mutually reinforce the phenomenon of smog.

\section{Decision-making problems in shaping environmentally friendly transport systems}

As mentioned before, shaping of the transport system in Poland results, on the one hand, from the forecasts of transport needs and the second from adapting the infrastructure and requirements of law to the standards and requirements of the European Union. The European Commission pays particular attention to the need for sustainable development of transport and environmentally friendly transport. Minimizing the negative impact of transport on the natural environment, and at the same time meeting expectations as to transport capacity, seem to be opposite objectives. It is therefore necessary to look for a solution that satisfies these positions.

Despite the fact that activities to reduce the negative effects of transport are constantly being taken, the continuous increase in the number of carried people and loads causes the effects of these activities are reduced to a large extent by the increased transport performance of both freight and passenger transport.

Summing up the planning of the development of the national transport system taking into account the aspects of environmental protection, it is not only related to the operational objectives of transport policy, but also to environmental issues such as air, soil and water pollution, noise or vibrations emitted by means of transport [19, 20].

The pollutant emission test is a complex process and requires the use of specialized equipment. There are various methods of conducting research. The most general classification is the division into tests in laboratory conditions and in real conditions. In the developed simulation model, the results of research on the emissivity of road transport in real conditions were taken into account as part of the EMITRANSYS project. These tests identified functional dependencies of the actual emission of particular harmful exhaust compounds from the parameters of the traffic flow, including vehicle speeds, as well as the type of transport means (capacity/load of the vehicle, Euro class, type of fuel).

The pursuit of a sustainable transport system is based on its appropriate shaping and organization in a way that allows achieving such a method of meeting the demand for transport due to the division of resources, for which it will limit the difficulties in users access to the transport system while reducing the congestion of the system and its excessive nuisance to the environment . To achieve this goal, IT tools are used that enable modelling of transport systems and then running on the obtained experimental models.

Due to the importance of transport infrastructure in meeting transport needs of passengers and transport of goods in the model, national and voivodship roads as well as railway lines and operated inland and aerial routes were taken into account. Transport networks of individual types of transport have been imposed on each other and connected in appropriate nodes, thus enabling the change in modes of transport to be included in the simulation model [12]. 
Due to the adopted detail of the EMITRANSYS simulation model, it was necessary to aggregate stops located in the area of one transport node. Moreover, in the simulation model, local communication lines identified as intra-district were omitted.

\section{Decision model for sustainable transport systems}

\subsection{General assumptions}

When analysing or assessing any phenomenon, process or system, the point of view from which this analysis or assessment will be carried out should always be specified. In the case of a sustainable transport system, the assessment indicator may be, for example, emission levels, external costs [9], quality of tasks, etc.

Considering the above, the following types among elements of a sustainable transport system have been distinguished:

- transport origin points,

- points of change of road characteristics and change of the type of transport means together with the accompanying point infrastructure of transport,

- transport destination points,

- transport links between the above-mentioned points appearing as existing linear transport infrastructure,

- means of transport, including economic parameters and characteristics of harmful compounds emitted,

- organization and communication networks.

The tool for analysing and assessing the functioning of existing or designed systems is a model in which the properties of the real system, which are important from the point of view of the research objective, should be mapped [8]. Formally, the Model of Proecological Transport System (MEST) was recorded as an ordered four in the following forms $[10,11]$ :

$$
\text { MEST }=\langle\text { GE, FE, QE, OE }\rangle
$$

where: MEST - model of a proecological transport system, GE - structure of a proecological transport system, FE set of characteristics of proecological structure elements of the transport system, $\mathbf{Q E}$ - volume of transport tasks, which MEST should realize, $\mathbf{O E}$ - organization.

Due to the dominating share of road and rail transport in the transport of passengers and goods in Poland, in the MEST mathematical model only these two branches of transport were taken into account (there is the possibility of extending the model with other transport modes) [23]. The transport network was identified and then analysed analytically, i.e. elements of point and linear transport and logistics infrastructure.

\subsection{Parameters of the model}

The MEST model also includes the characteristics of road infrastructure, means of transport and parameters of harmful exhaust gas compounds [14]. Elements of the analysed system were formally recorded. The most important of the used signs are listed below:

i, i', i' $\quad$ index of the transport node, i, i', i', $\in \mathbf{W E}$

st index of the type of transport mean, st $\in \mathbf{S T}$

rsp engine type index, $r s p \in \mathbf{R S P}$

$\mathrm{s} \quad$ exhaust type index, $\mathrm{s} \in \mathbf{S}$ o area type index, o $\in \mathbf{O}$

neu Euro standard index, neu $\in$ NEU

$\mathrm{V} \quad$ speed index, $\mathrm{v} \in \mathbf{V}$

$\mathrm{k}$ index of transport type (railway, road, air, ...), $\mathrm{k} \in \mathbf{K}$

$\mathrm{p} \quad$ road index in relation of carriage, $(\mathrm{a}, \mathrm{b}) \in \mathbf{E}$, $\mathrm{p} \in \mathbf{P}^{\mathrm{ab}}$

$\mathrm{m} \quad$ index of the transport kind (e.g. passenger), $\mathrm{m} \in \mathbf{M}$

$\operatorname{nr}(\mathrm{st}) \quad$ number of euro standard for vehicle type st,

$1(\mathrm{i}, \mathrm{i}$ ') length of (i,i') transport connection,

$\mathrm{x}(\mathrm{a}, \mathrm{b}, \mathrm{m})$ demand for transport in relation $(\mathrm{a}, \mathrm{b}) \in \mathbf{E}$ of the $\mathrm{m}$ kind of transport,

$q(s t, m)$ the average use of the load/capacity of the vehicle type st of $m$ kind of transport,

d(i,i') capacity of (i,i') transport connection,

$\chi(\mathrm{k}) \quad$ economic efficiency of transports made by $\mathrm{k}$ transport subsystem,

$\mu(\mathrm{k}) \quad$ economic efficiency of transport work performed by k transport subsystem,

em(s,st,n emission of harmful exhaust gas s by type of eu,rsp,v) vehicle st with engine type rsp comply with neu emission standard when driving at a speed $\mathrm{v}$ per unit distance,

neu(i, $\left.i^{\prime}\right) \quad$ number of the acceptable euro standard for the section $\left(i, i^{\prime}\right) \in \mathbf{L E}$

$\mathrm{q}(\mathrm{rt}, \mathrm{k}) \quad$ level of transport carried out by $\mathrm{k}$ transport subsystem rt type of transport,

$\mathrm{ES}(\mathrm{s}, \mathrm{k})$ total emission of the harmful component of exhaust gas through $\mathrm{k}$ transport subsystem,

$\mathrm{L}(\mathrm{rt}, \mathrm{k}) \quad$ average transport distance under $\mathrm{k}$ transport subsystem for rt type of transport,

$\mathrm{KS}(\mathrm{k}) \quad$ cost of operation $\mathrm{k}$ transport subsystem.

\subsection{Boundary conditions and criteria for the assessment of the solution's quality}

As the basic criteria for the assessment of distribution of traffic flow on transport network in the area of shaping the proecological transport system, the economic as well as ecological and social indicators were taken into account in the developed model. One of the most important criteria for assessing the distribution of a traffic flow in the model of proecological transport system are the emission levels of individual harmful exhaust gas emissions emitted by transport means performing transport tasks in a selected area of the transport network:

$$
\begin{aligned}
& \forall \mathrm{s} \in \mathbf{S} \quad \forall \mathrm{k} \in \mathbf{K} \quad \mathrm{ES}(\mathrm{s}, \mathrm{k})= \\
& =3600 \cdot 10^{-6} \sum_{(\mathrm{a}, \mathrm{b}) \in \mathbf{E}} \sum_{\mathrm{p} \in \mathbf{P}^{\mathrm{ab}}} \sum_{\mathrm{st} \in \mathbf{S T}(\mathrm{k})} \sum_{\mathrm{ne} \in \mathbf{N E}} \sum_{\mathrm{rs} \in \mathbf{R S}} \mathrm{xp}(\mathrm{p}, \mathrm{a}, \mathrm{b}, \mathrm{st}, \mathrm{ne}, \mathrm{rs}) \times
\end{aligned}
$$

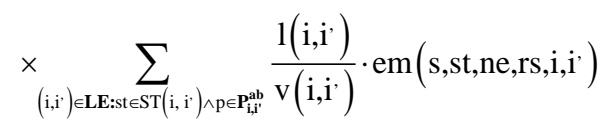

Next developed criterion for assessing the distribution of traffic flow on the transport network, which is economically significant, is the direct transport cost. Taking into account transport performance as a result of the functioning of the transport system, the index of economic efficiency of transport work is determined, while taking into account the level of transport - the index of economic efficiency of 
transport. Assuming the possibility of decomposing the operating costs of the transport system to the costs of the passenger transport subsystem and freight transport, the analytical form of these indicators was recorded in the form of:

$$
\begin{gathered}
\forall \mathrm{k} \in \mathbf{K} \quad \mu(\mathrm{k})=\frac{\sum_{\mathrm{r} \in \mathbf{R} \mathbf{T}} \mathrm{q}(\mathrm{rt}, \mathrm{k}) \cdot \mathrm{L}(\mathrm{rt}, \mathrm{k})}{\mathrm{KS}(\mathrm{k})} \\
\forall \mathrm{k} \in \mathbf{K} \quad \chi(\mathrm{k})=\frac{\sum_{\mathrm{r} \in \mathbf{R T}} \mathrm{q}(\mathrm{rt}, \mathrm{k})}{\mathrm{KS}(\mathrm{k})}
\end{gathered}
$$

The model includes, among others [13]:

1. constraints on the fulfilment of transport needs,

2. constraints resulting from the specified capacity of connections (sections) of roads,

3. constraints imposed on the traffic flow,

4. constraints on enter the area due to the acceptable Euro standard,

5. constraints on type of decision variable,

6. constraints on not to exceed the available number of transport means,

7. constraints on the possibility of moving transport means of particular types on transport connections,

8. constraints on the possibility of servicing routes with vehicles meeting specific emission standards,

9. and other constraints.

\section{Examples of the practical application of the EMITRANSYS model}

In the last part of the article the possibility of using the EMITRANSYS model for conducting analyses will be presented. The developed EMITRANSYS simulation model of the environment-friendly transport system has been divided into two interdependent models:

1. network model that maps the point and linear infrastructure of the transport system and describes the availability of system users to specific branches and means of transport. It consists of, among others, with:

- sections of roads, railways, inland roads, air corridors etc.,

- nodes being their destinations, origins or connection elements,

- communication areas, nodes and public transport stops,

- public transport sections and lines with timetables,

2. demand model containing data on current and future transport needs, including the demand for passenger travel and cargo transportation between specific areas of the network.

In example it has been assumed that the movement of goods can be implemented from any node on the transport network, to another located along the same or different communication path. For this reason, in fact, for the same route of carriage will be chosen different routes of carriage, and hence different types of transport.

One of the tools for estimating the level of environmental pollution used in the EMITRANSYS simulation model is the HBEFA module implemented in PTV VISUM. It serves to map pollutant emissions from transport network connections based on the distribution of the traffic flow, the assumed vehicle structure and unit emission factors (including $\mathrm{CO}_{2}, \mathrm{CO}, \mathrm{HC}, \mathrm{NO}_{\mathrm{x}}, \mathrm{PM}_{\mathrm{x}}$ ). This module contains a database that includes historical data from 1990 to forecasts for 2035. The structure of vehicles includes participation within a given category (light delivery vans, lorries, tractors with semitrailer, refrigerated vehicles), motorcycles, passenger cars, city buses and tourist buses) for different types distinguished in terms of e.g. capacity, number of seats, engine type (gasoline, diesel). This module makes it possible to determine the emission of pollutants on the transport network for a given vehicle structure.

One of the possibility of using EMITRANSYS simulation model [15] is the estimation of the emission volumes of the previously mentioned harmful substances $\left(\mathrm{CO}, \mathrm{NO}_{\mathrm{x}}, \mathrm{HC}\right)$ by particular vehicle types, with a specific emission standard and with a specific engine type. Thanks to this, after the distribution of flow of passengers and loads on the transport network of Poland, the level of emission of harmful exhaust compounds was estimated on individual sections of the Polish road network $[16,22]$. In addition, the emissions from passenger transport were distinguished. Obtained results for 2015, 2020 and 2025 are shown in Figs 3-5.

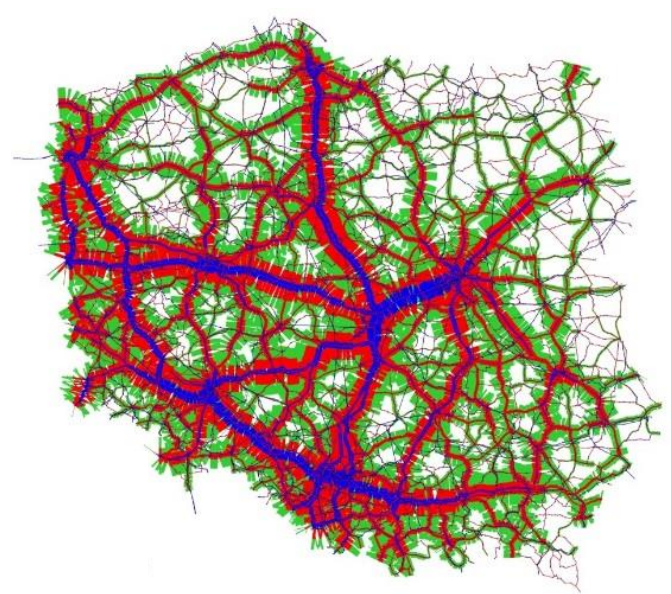

Fig. 3. The level of emissions of harmful compounds by passenger transport in 2015 in $\mathrm{g} / \mathrm{km}$ (legend: blue line - HC, red line - CO, green line $-\mathrm{NO}_{\mathrm{x}}$ ) [8]

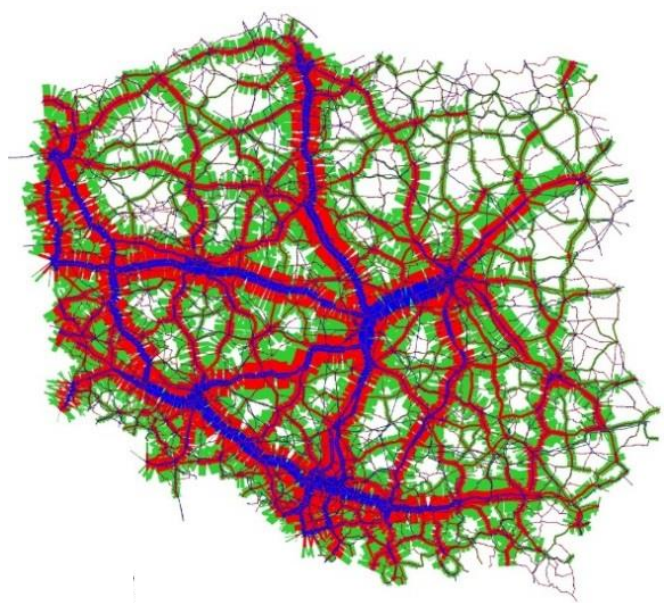

Fig. 4. The level of emissions of harmful compounds by passenger transport in 2020 in $\mathrm{g} / \mathrm{km}$ (legend: blue line - HC, red line - CO, green line $\left.-\mathrm{NO}_{\mathrm{x}}\right)[8]$ 


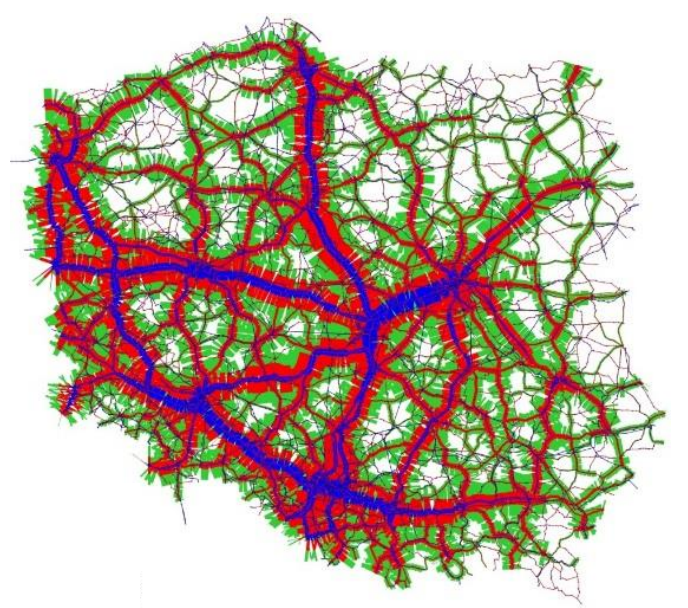

Fig. 5. The level of emissions of harmful compounds by passenger transport in 2025 in $\mathrm{g} / \mathrm{km}$ (legend: blue line $-\mathrm{HC}$, red line - $\mathrm{CO}$, green line $-\mathrm{NO}_{\mathrm{x}}$ ) [8]

\section{Conclusions}

The EMITRANSYS simulation model presented in the paper is an attempt to answer the questions posed by transport decision makers that deal with proecological solutions for this system. Both the mathematical model and its implementation in the PTV VISUM program can provide tools to support decisions in the area of developing a proecological transport system at both operational and strategic levels. These decisions may concern, inter alia, modernization of the infrastructure elements of the transport system or the reorganization of traffic.

EMITRANSYS model, moreover, can be applied to:

- studies on the impact of external costs on the structure of traffic, the attractiveness of transport or between different transport service providers,

- analysis and assessment of the impact of changes in the structure of road vehicles in the field of Euro standards on the emission of harmful exhaust compounds produced by road vehicles,
- research on inter-branch interactions taking into account the costs of emission of harmful exhaust fumes emitted by means of transport,

- identification of areas in urban agglomerations in which the emission of harmful compounds exceeds the acceptable standards,

- verification of the strategy of protection of areas particularly valuable for nature in order to prevent the negative effects of transport activities,

- multifaceted assessment of greenhouse gas emissions and other harmful exhaust components related to transport activities,

- research into the strategy for the development of a sustainable transport system by analysing investments on the road and rail network, taking into account aspects of transport ecology,

- distribution of financial resources for investments and modernization of transport infrastructure elements in Poland.

Summing up thanks to the developed implementation, it is possible to simulate the assessment of the impact of decisions on the development of the transport network and legislative conditions of road transport on pollution of the environment, taking into account the functional dependence between technical and organizational consequences of these decisions and the level of harmful exhaust emissions.

\section{Acknowledgements}

Scientific work carried out partly as part of the project "Shaping a proecological transport system" (EMITRANSYS), financed by the National Center for Research and Development, carried out by the scientific consortium of the Transport Faculty of the Warsaw University of Technology and the Faculty of Machines and Transport of the Poznan University of Technology and partly as part of the statutory work of the Warsaw University of Technology.

\section{Bibliography}

[1] AMBROZIAK, T., GOŁĘBIOWSKI, P., PYZA, D. et al Identification and analysis of parameters for the areas of the highest harmful exhaust emissions in the model EMITRANSYS. Journal of KONES Powertrain and Transport. 2013, 20(3), 9-20.

[2] AMBROZIAK, T., JACYNA, M., GOŁĘBIOWSKI, P. et al. Wpływ rozłożenia potoku ruchu w sieci transportowej na poziom emisji $\mathrm{CO}_{2}$ przez środki transportu. Prace Naukowe Politechniki Warszawskiej. Transport. 2013, 97, 9-18.

[3] EUROPEAN ENVIRONMENT AGENCY. Air quality in Europe - 2018 report. Copenhagen 2018.

[4] GALKIN, A. Urban environment influence on distribution part of logistics systems. Archives of Transport. 2017, 42(2), 7-23.

[5] GOŁĘBIOWSKI, P., JACHIMOWSKI, R., LEWCZUK, K. et al. Uwarunkowania prawne kształtowania proekologicznego systemu transportowego. Prace Naukowe Politechniki Warszawskiej. Transport. 2013, 97, 135-145.

[6] GRABAREK, I. Nowe wyzwania w projektowaniu innowacyjnych systemów transportowych. Problemy Jakości. 2016, 12, 35-43.
[7] INSPEKCJA OCHRONY ŚRODOWISKA. Ocena jakości powietrza w strefach w Polsce za rok 2017. 2018 [online] http://www.gios.gov.pl.

[8] JACYNA, M., KŁODAWSKI, M., WASIAK, M., ŻAK, J. Model symulacyjny EMITRANSYS jako narzędzie do analizy i planowania rozwoju krajowego systemu transportowego. Oficyna Wydawnicza Politechniki Warszawskiej. Warszawa 2014.

[9] JACYNA, M., LEWCZUK, K., SZCZEPAŃSKI, E. et al. Effectiveness of national transport system according to costs of emission of pollutants. In: Safety and Reliability: Methodology and Applications [CD-ROM]. CRC Balkema. 2015, 559-567.

[10] JACYNA, M., MERKISZ, J. Proecological approach to modelling traffic organization in national transport system. Archives of Transport. 2014, 30(2), 31-41.

[11] JACYNA, M., WASIAK, M., LEWCZUK, K., KŁODAWSKI, M. Simulation model of transport system of Poland as a tool for developing sustainable transport. $\mathrm{Ar}$ chives of Transport. 2014, 31(3), 23-35.

[12] JACYNA, M., ŻAK, J., JACYNA-GOŁDA, I. et al. Selected aspects of the model of proecological transport system. Journal of KONES Powertrain and Transport. 2013, 20(3), 193-202. 
[13] JACYNA, M., ŻAK, J., PYZA, D., GOŁĘBIOWSKI, P. Technical and environmental limitations of pro-ecological transport system designing. Journal of KONES Powertrain and Transport. 2014, 21(4), 555-564.

[14] JACYNA-GOŁDA, I., ŻAK, J., GOŁĘBIOWSKI, P. Models of traffic flow distribution for scenarios of the development of proecological transport system. Archives of Transport. 2014, 32(4), 17-28.

[15] JACYNA-GOŁDA, I., GOŁĘBIOWSKI, P., IZDEBSKI, M. et al. The evaluation of the sustainable transport system development with the scenario analyses procedure. Journal of Vibroengineering. 2017, 19(7), 5627-5638.

[16] JACYNA-GOŁDA, I., LEWCZUK, K., SZCZEPAŃSKI, E., GOŁĘBIOWSKI, P. Rozłożenie ruchu w sieci transportowej z zastosowaniem modelu EMITRANSYS w aspekcie planowania rozwoju systemu transportowego. Oficyna $W y$ dawnicza Politechniki Warszawskiej. Warszawa 2014.

[17] MERKISZ, J., PIELECHA, J., RADZIMIRSKI, S. Emisja zanieczyszczeń motoryzacyjnych $\mathrm{w}$ świetle nowych przepisów Unii Europejskiej. Wydawnictwa Komunikacji $i$ Łączności. Warszawa 2012.

[18] MUNTEAN, M., GUIZZARDI, D., SCHAAF, E. et al. Fossil $\mathrm{CO}_{2}$ emissions of all world countries - 2018 Report. European Union, Publications Office of the European Union. 2018.
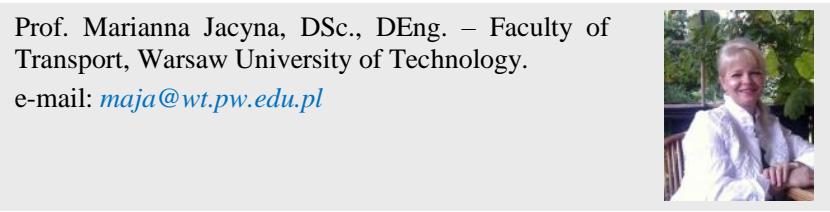

Prof. Jolanta Żak, DEng. - Faculty of Transport, Warsaw University of Technology.

e-mail:j.zak@wt.pw.edu.pl
[19] NADER, M. Drgania i hałas w transporcie. Wybrane zagadnienia. Oficyna Wydawnicza Politechniki Warszawskiej. Warszawa 2016.

[20] ORCZYK, M., TOMASZEWSKI, F. Studies and assessment of transport noise in Poznan. Archives of Transport. 2016, 37(1), 43-54.

[21] PYZA, D., JACYNA-GOŁDA, I., GOŁDA, P., GOŁĘBIOWSKI, P. Alternative fuels and their impact on reducing pollution of the natural environment. Rocznik Ochrona Środowiska. 2018, 20, 819-836.

[22] WASIAK, M., KŁODAWSKI, M., LEWCZUK, K. et al. Chosen aspects of simulation model to designing proecological transport system. Journal of KONES Powertrain and Transport. 2014, 21(4), 525-532.

[23] ŻAK, J., GOŁĘBIOWSKI, P., POPIELA, K. Selected aspects of the environmental friendliness assessment of railway transport using the indicator method. Transport Means 2018. Proceedings of 22nd International Scientific Conference. Part II, Kaunas. Publishing House "Technologija", 2018, 950-955.

[24] ŻAK, J., GOŁĘBIOWSKI, P. Comparative analysis of the rail and road transport in the $\mathrm{CO}_{2}$ emission. Combustion Engines. 2015, 3, 944-951.

Piotr Gołębiowski, DEng. - Faculty of Transport, Warsaw University of Technology.

e-mail:pgolebiowski@wt.pw.edu.pl 